\title{
Epidemiology, diagnosis and therapy of Theileria equi infection in Giza, Egypt
}

\author{
Fayez A. Salib ${ }^{1}$, Raouf R. Youssef ${ }^{1}$, Laila G. Rizk ${ }^{2}$, Samer F. Said ${ }^{3}$
}

1. Department of Medicine and Infectious Diseases, Faculty of Veterinary Medicine, Cairo University, Egypt. 2. Department of Biochemistry, Nutritional Deficiency, Diseases and Toxicology, Animal Health Research institute, Dokki, Giza, Egypt. 3. El-Haram Reproduction Institute, Giza, Egypt.

Corresponding author: Fayez A. Salib, email: fayez_vetmed@hotmail.com, Telephone.: +20 109578826, Fax: +20235725240

Received: 13-06-2012, Accepted: 03-07-2012, Published online: 30-11-2012

\section{How to cite this article:}

Salib FA, Youssef RR, Rizk LG and Said SF (2013) Epidemiology, diagnosis and therapy of Theileria equi infection in Giza, Egypt, Vet World 6(2): 76-82. doi: 10.5455/vetworld.2013.76-82

\begin{abstract}
Aim: To study the prevalence of Theileria equi among horses in different age groups, both sexes, months and seasons of the year, and regions of Giza governourate. Studying the changes in the blood picture, blood chemistries, liver enzymes associate with T.equi infections in horses. Evaluating IFA and CFT at different dilutions in the serodiagnosis of T.equi infections in horses. Evaluating four anti-Theileria medication regimens (diminazine aceturate, imidiocarb 7\%, buparvaquone and a combination of imidiocarb $7 \%$ and buparvaquone) in treatment of T.equi infections in horses.
\end{abstract}

Materials and Methods: Total of 149 horses were examined by clinical signs and blood smears. Fortey whole blood samples from T.equi infected horses were examined to measure haemoglobin, total RBCs count and PCV. Fortey serum samples from T.equi infected horses were examined to measure total bilirubin, direct bilirubin, ALT and AST enzymes. Serum samples from T.equi infected (40) and non infected (14) horses were tested by indirect fluorescent antibody test (IFA) and complement fixation test (CFT) at different dilutions. Four groups of T.equiinfected horses (A,B,C,D), each group was represented by 10 horses and was separately treated with diminazine aceturate, imidiocarb 7\%, buparvaquone and a combination of imidiocarb $7 \%$ and buparvaquone respectively.

Results: the prevalence of T.equi was $41.61 \%$ in totally examined horses. The prevalence was higher in males than females. The highest prevalence was among age group ranged from 5-10 years as (22.81\%). The highest prevalence was in July and was recorded as $(25.81 \%)$ and the disease was more prevalent in summer than winter. The highest prevalence was recorded in Nazlet-alsamman as $(51.61 \%)$. Equine theileriosis was clinically characterized by fever, haemoglobinuria, oedema, anaemia and icterus. The best dilution for IFA was 1/160 where sensitivity, specificity and accuracy were the highest for this test as (98\%), (92.86\%) and (97.44\%) respectively. The best dilution for CFT was 1/32 where sensitivity, specificity and accuracy were collectively the best as $(90 \%),(92.86 \%)$ and $(90.74 \%)$ respectively.

Conclusion: It was concluded that T.equi is prevalent among horses in Giza governourate, its prevalence is varied according to the age, sex of horses, months, seasons and regions. T.equiinfections in horses are accompanied with changes in blood pictures, blood chemistries and liver enzymes. Both IFA and CFT could be used for the serodiagnosis of T.equi. The used four anti-Theileria medication regimens have the same ability to eradicate T.equi from the infected horses.

Keywords: diagnosis, Egypt, epidemiology, Giza, Theileria equi, therapy

\section{I ntroduction}

Equine theileriosis, an OIE list disease, caused by tick borne Theileria equi, is responsible for important economic losses in the equine industry. The disease is endemic in tropical and subtropical regions of the world, including Southern Europe, Africa, The Middle East, Asia, South America and Central America. Disease can occur in peracute, acute and chronic forms. In animals there are fever, anemia, jaundice, haemoglobinuria and in some cases death can occur [14]. Donkeys usually remain asymptomatic carriers with positive antibody titre throughout life. The clinical form of the disease is diagnosed by peripheral blood smear examination, but in carrier donkeys it is very difficult to demonstrate the parasite in stained blood smears as the parasitaemia is extremely low. The Seroprevalence of the disease was studied in Saudi Arabia [3], in Jordan [1], in Mexico [5], in Brazil [11], in Netherland [4], in Venezuela [12] and in Repbublic of Korea [19]. The polymerase chain reaction was used to diagnosis of T.equi prevalence in Israel [21], in North-Eastern Mongolia [20] and in Poland [2]. The diagnosis of equine theileriosis depends on the detection of Theileria equi in the blood cells in acute cases. Screening antibodies specific to Theileria equi in the sera of horses is very important to detected chronic cases of equine theileriosis. The treatment of equine theileriosis includes both specific and supportive lines of therapy. The specific line of treatment depends on using anti- Theileria equi drugs with control of ticks while supportive line was carried out on fluid therapy, antipyretics, blood tonics and stomachics.

The aim of this study was to record the clinical signs of T.equi infection in horses, to determine the prevalence of T.equi in horses in Giza governourate, to record the changes in blood picture and blood 
chemistry associated with equine theileriosis before and after treatment, to evaluate complement fixation test and indirect fluorescent antibody technique for the diagnosis of equine theileriosis and to evaluate different drugs for the treatment of equine theileriosis.

\section{Materials and Methods}

Animals: A total of 149 horses showed signs of fever, emaciation and exhaustion were examined for detection of blood parasites. The blood smears, whole blood and serum samples were collected from each animal. The Theileria infected horses were classified into groups and each group was treated separately. The blood smears, whole blood and serum samples were collected post-treatment to evaluate the efficacy of anti-theileria medications. The serum samples were used for complement fixation test and indirect fluorescent antibody technique to evaluate both them in comparison the gold standard (presence of T.equi in blood smears). The horse was considered Theileria free after three negative successive blood smears. Animal ethics committee permit us to do this research work on horses. All horses were cared according to animal ethics committee instructions.

Samples: Blood smears were collected from ear vein of horses, stained and microscopically examined as previously described [24], the examined horses were classified into two groups, Theileria infected and Theileria non infected.

Blood samples were collected by jugular venipuncture at the times of the disease and one month following the last treatment. The collected blood was divided into two parts in two $10 \mathrm{ml}$ partial -vacuum tubes. The first tube contained Ethylene diamine tetraacetic acid (EDTA) at a concentration of one $\mathrm{mg} \mathrm{ml}^{-1}$ blood. The second tube contained no anticoagulant for separation of serum.

For examination of blood parasites, blood films were prepared at the time of sampling and stained with Giemsa stain. The collected whole blood samples were quickly examined to measure RBCs, packed cell volume and haemoglobin. Sera were separated from the second tube and stored at $-20^{\circ} \mathrm{C}$ until examination .

Clinical examination: This work had been carried out during one year in districts of Giza governourate ,Egypt. A total of 149 horses of both sexes and of different age groups showed fever, emaciation and exhaustion were examined. Data of animals and owners were recorded. The animals were clinically examined by measuring body temperature, pulse and respiration rates. Inspection of mucous membranes and lymph nodes was also done [16]. The presence of ticks and urine colour were also taken in consideration to diagnose equine theileriosis.

\section{Parasitological examination:}

a-Blood smear: As previously mentioned [24], Blood samples were collected from ear veins and small drop of fresh blood were placed at the end of one slide and by the other slide in angle of fourty fife touched the drop of blood by the end of the slanted slide so the blood run in space beneath it. The slanted slide was drawn quicly and the blood was pulled behind. The blood smear was died in air, fixed by absolute methyl alcohol and was stained with Giemsa $10 \%$ for 20 minutes in neutral phosphate buffer saline then was washed and dried.

b-Thick drop test: Blood samples were collected from ear veins and small blood droplets were spread moderately in a clean glass slide and mixed with tooth picks, dried on incubator $37^{\circ} \mathrm{C}$ and stained for twenty minutes with Giemsa stain in neutral phosphate buffer then wash and dry and examined microscopically as carried out [24].

Whole blood examination: Total red blood cell (RBC) counts were made by a haemocytometer. The international microhaematocrit method was employed for packed cell volume (PCV) determination; the haemoglobin concentration $(\mathrm{Hb})$ was obtained using a spectrophotometric method [6].

Serum chemistry: Estimations of total and direct bilirubin, Alanine aminotransferase(ALT), aspirate aminotransferase (AST), were carried out [8].

\section{Serodiagnosis:}

a-Indirect Fluorescent Antibody Test: Preparation of antigen, chemicals and technique of indirect fluorescent antibody test was done according to methods stated [14]. Fifty four serum samples (40 from Theileria infected and 14 from Theileria free horses) were tested by indirect fluorescent antibody test . The sera were diluted from $1 / 80$ to $1 / 320$.

b-Complement Fixation Test: Preparation of antigen, chemicals and technique of complement fixation test was done according to methods stated [14]. Fifty four serum samples ( 40 from Theileria infected and 14 from Theileria free horses) were tested by complement fixation test. The sera were diluted from $1 / 8$ to $1 / 128$.

Therapy: The therapy of Theileria infected horses was done according to [16] and the recomendations of the companies produced anti-Theileria drugs. Theileria infected horses were classified into four groups, each group consisted of 10 horses and it was treated separately with anti-Theileria medication as the following:

Group-A was treated with Diminazine aceturate (Trypanodad DADvet dar al dawa veterinary) at dose rate of $3.5 \mathrm{mg} / \mathrm{kg}$ body weight by deep intramuscular injection.

Group-B was treated with Imidiocarb (Imidox, parnel laporatories (aust) $7 \%$ at dose rate of $120 \mathrm{mg} / 100 \mathrm{~kg}$ body weight by intramuscular injection.

Group-C was treated with buparvaquone (Butalex, Schering-plough animal health $50 \mathrm{mg} / \mathrm{ml}$ ) at dose rate of $50 \mathrm{mg} / 20 \mathrm{~kg}$ body weight by intramuscular injection.

Group-D was treated with a combination of Imidiocarb 
Table-1. Clinical findings among infected Table-2. Age and sex of T.equi infected horses

horses

\begin{tabular}{|c|c|c|}
\hline \multirow[t]{2}{*}{ Clinical sign } & \multicolumn{2}{|c|}{ Infected horses } \\
\hline & No. & $\%$ \\
\hline Fever & 62 & 100 \\
\hline Red urine & 45 & 72.6 \\
\hline Jaundice and anemia & 38 & 61.3 \\
\hline Tick infestation & 28 & 45.2 \\
\hline Oedema & 12 & 19.4 \\
\hline
\end{tabular}

\begin{tabular}{|c|c|c|c|c|}
\hline \multirow[t]{2}{*}{ Parameters } & \multicolumn{2}{|c|}{ Male } & \multicolumn{2}{|c|}{ Female } \\
\hline & No. & $\%$ & No. & $\%$ \\
\hline Less than 1 year & 0 & 0 & 0 & 0 \\
\hline $1-2$ years & 1 & 1.61 & 0 & 0 \\
\hline 2-5 years & 18 & 29.03 & 1 & 1.61 \\
\hline $5-10$ years & 29 & 46.78 & 5 & 8.06 \\
\hline $10-15$ years & 6 & 9.68 & 2 & 3.23 \\
\hline More than 15 years & 0 & 0 & 0 & 0 \\
\hline Total & 54 & 87.09 & 8 & 12.90 \\
\hline
\end{tabular}

Table-3. Temporal distribution of T.equi infected horses.

\begin{tabular}{lcc}
\hline Months & \multicolumn{2}{c}{ Infected horses } \\
& No. & $\%$ \\
\hline January & 0 & 0 \\
February & 0 & 0 \\
March & 1 & 1.61 \\
April & 4 & 6.45 \\
May & 6 & 9.68 \\
June & 10 & 16.13 \\
July & 16 & 25.81 \\
August & 12 & 19.35 \\
September & 7 & 11.29 \\
October & 4 & 6.45 \\
November & 2 & 3.23 \\
December & 0 & 0 \\
Total & 62 & 100 \\
\hline
\end{tabular}

(Imidox, parnel laporatories (aust))7\% at dose rate of $120 \mathrm{mg} / 100 \mathrm{~kg}$ by intramuscularinjection and buparvaquone (Butalex, Schering-plough animal health $50 \mathrm{mg} / \mathrm{ml}$ ) at dose rate of $25 \mathrm{mg} / 20 \mathrm{~kg}$ body weight by intramuscular injection.

All horses were examined before and after treatment by blood smear, blood picture, blood chemistry, IFA and CFT. Each anti-theileria medication was evaluated clinically by disappearance of disease symptoms; haematologically by examinations of blood smears, blood pictures and blood chemistries; and serologically by results of indirect fluorescent antibody test and complement fixation tests before and after treatments.

Supportive treatment was given to all Theileria infected horses. It was included Metamizol (Chemical Industries Development (CID) at dose rate of 10-20 ml per horse by intravenous injection).

Poly-Minerals mixture as blood tonics was added on animal ration. Cafosal (Arabcomed) at dose rate of $5.0-25.0 \mathrm{ml}$ according to body weight by intravenous injection). Glucose 5\% (El-nasr company) at dose of one litre for $100 \mathrm{~kg} \mathrm{b.w.} \mathrm{by} \mathrm{intravenous} \mathrm{infusion).}$

Doramectin (Dectomax, Pfizer) at dose rate of $1 \mathrm{ml} / 50 \mathrm{~kg}$ body weight by intramuscular injection to control ticks.

Statistical analysis: Both indirect fluorescent antibody test and complement fixation test were statistically evaluated $[7,17,22]$. The gold standard is the presence of Theilera equi merozoite in RBCs or schizont in lymphocyte The horse was considered Theileria free after three negative successive blood smears.

\section{Results}

The clinical signs observed in Theileria infected horses are illustrated in table- 1 .

The clinical signs recorded were fever (39.5-
Table-4. Spatial distribution of T.equi infected horses.

\begin{tabular}{lcc}
\hline Places & \multicolumn{2}{c}{ Infected horses } \\
& No. & $\%$ \\
\hline Nazlet-alsamman & 32 & 51.61 \\
Kafr- algabal & 20 & 32.26 \\
Abo- ser & 3 & 4.84 \\
Sakkara & 4 & 6.45 \\
Harrania & 1 & 1.61 \\
Shobramant & 2 & 3.25
\end{tabular}

$41 \mathrm{C}^{\circ}$ ), Jaundice, red urine, oedema, anaemia and ticks infestation.

The prevalence: Prevalence of Theileria equi was (62 out of 149 horses $),(41.61 \%)$ in examined horses. It was higher in males (54) than females (8), it was recorded as $(36.24 \%)$ and $(5.36 \%)$ respectively. The prevalence was the highest in age group ranged from 5-10 years where 34 horses ( 29 males and 5 females) were infected with T.equi as shown in table-2. The distribution of T.equi infected horses according to months were illustrated in table-3, the highest number of infected horses was in July $(16,25.21 \%)$. The distribution of T.equi infected horses according to regions were illustrated in table-4 the highest number of infected horses was in Nazlet-alsamman (32 51.61\%).

The evaluation of I FA and CFT: The results of statistical evaluation of IFA and CFT are presented in tables (5 and 6). Statistically, the best dilutions of IFA and CFT for diagnosis of T.equi were $1 / 160$ and $1 / 32$ respectively.

Therapy: The four anti-Theileria medications have the same ability to eradicate T.equi from horse blood and improve clinical signs, blood pictures, blood chemistry and also lower antibody titres in sera of horses that were very clear at one month post-treatment as presented in tables (7 and 8).

\section{Discussion}

Equine piroplasmosis is caused by the protozoa Babesia caballi or Theileria equi (formerly Babesia equi). Both organisms belong to the phylum Apicomplexa and order Piroplasmida. They can infect horses concurrently. Other related protozoa such as Babesia bovis (the organism that causes bovine babesiosis) have been reported rarely in horses. It affects horses, mules, donkeys and zebras. Zebras are an important 
Table-5. Results of statistical evaluation of IFA and CFT at different dilutions.

\begin{tabular}{|c|c|c|c|c|c|c|c|c|}
\hline \multirow[t]{2}{*}{ Particulars } & \multicolumn{3}{|c|}{ IFA (\%) } & \multicolumn{5}{|c|}{ CFT (\%) } \\
\hline & $1 / 80$ & $1 / 160$ & $1 / 320$ & $1 / 8$ & $1 / 16$ & $1 / 32$ & $1 / 64$ & $1 / 128$ \\
\hline Sensitivity & 100.00 & 98.00 & 10.00 & 100.00 & 97.50 & 90.00 & 82.50 & 10.00 \\
\hline Specificity & 14.28 & 92.86 & 100.00 & 42.86 & 78.57 & 92.86 & 92.86 & 100.00 \\
\hline PD + & 76.92 & 97.44 & 100.00 & 83.33 & 92.86 & 97.30 & 97.06 & 100.00 \\
\hline PD - & 100.00 & 86.87 & 28.00 & 100.00 & 0 & 76.47 & 65.00 & 28.00 \\
\hline False -ve Ratio & 0 & 5.00 & 90.00 & 83.33 & 2.50 & 15.00 & 17.50 & 90.00 \\
\hline False + ve Ratio & 85.71 & 6.67 & 0 & 57.14 & 21.43 & 7.14 & 7.14 & 0 \\
\hline Apparent prevalence & 96.30 & 7.22 & 7.41 & 88.89 & 77.78 & 68.52 & 62.96 & 7.41 \\
\hline Tru prevalence & 74.07 & 74.07 & 74.07 & 74.07 & 74.07 & 74.07 & 74.07 & 74.07 \\
\hline Accuracy & 77.77 & 97.44 & 33.33 & 85.18 & 92.59 & 90.74 & 85.18 & 85.18 \\
\hline
\end{tabular}

Table-6. Results of Kappa values for IFA and CFT at different dilutions

\begin{tabular}{|c|c|c|c|c|c|c|}
\hline \multirow[t]{3}{*}{$\overline{\text { CFT }}$} & \multicolumn{6}{|c|}{ IFA } \\
\hline & \multicolumn{2}{|c|}{$1 / 80$} & \multicolumn{2}{|c|}{$1 / 160$} & \multicolumn{2}{|c|}{$1 / 320$} \\
\hline & Kappa Value & Significance & Kappa Value & Significance & Kappa Value & Significance \\
\hline $\begin{array}{l}1 / 8 \\
1 / 16 \\
1 / 32 \\
1 / 64 \\
1 / 128\end{array}$ & $\begin{array}{l}0.86 \\
0.24 \\
0.14 \\
0.12 \\
0.11\end{array}$ & $\begin{array}{l}\text { A.P.A. } \\
\text { F.A. } \\
\text { S.A. } \\
\text { S.A. } \\
\text { S.A. }\end{array}$ & $\begin{array}{l}0.49 \\
0.91 \\
0.91 \\
0.86 \\
0.60\end{array}$ & $\begin{array}{l}\text { M.A. } \\
\text { A.P.A. } \\
\text { A.P.A. } \\
\text { A.P.A. } \\
\text { M.A. }\end{array}$ & $\begin{array}{l}0.02 \\
0.04 \\
0.39 \\
0.40 \\
1.00\end{array}$ & $\begin{array}{l}\text { S.A. } \\
\text { S.A. } \\
\text { F.A. } \\
\text { F.A. } \\
\text { C.A. }\end{array}$ \\
\hline
\end{tabular}

$\mathrm{C} . \mathrm{A}=$ Complete Agreement $=1, \mathrm{~F} . \mathrm{A} .=$ Fair Agreement from $0.21-0.40, \mathrm{~A} . \mathrm{P} . \mathrm{A} .=$ Almost Perfect Agreement $>0.81, \mathrm{~S} . \mathrm{A} .=\mathrm{Slight}$ Agreement from $0-0.20$, S.A. = Substantial Agreement from $0.61-0.80$, P.A. = Poor Agreement $=0$, M.A. = Moderate Agreement from 0.41-0.60

reservoir for infection in Africa. The economic importance of this disease are concerned in weakness and inability of horse to work, cost of treatment and deaths.

In our study, the prevalence of Theileria equi was recorded as $41.61 \%$ (62 out of 149 horses) in examined horses by using blood films examinations. Piroplasms of $T$. equi are small measuring $2.0 \times 1.0 \mu \mathrm{m}$, circular, but mostly piriform and in the latter shape usually presented as a Maltese cross [13], that means it is in a group of 4 merozoites united by their top ends in the shape of a cross that found in a single red blood cell. Another stage found in lymphocyte of infected horses; which is Schizont of Theileria equi as presented in Figure-3.

The prevalence was higher in males (54) than females (8), it was recorded as (36.24\%) and (5.36\%) respectively. The sex of horses could play a role in infestation of T.equi according to the system of breeding and working of horses, most of females used for breeding while most of males used for working consequently working horses are more exposed to stress and immune suppression. While prevalence of Theileria equi was previously studied [23], they found that out of the 111 samples, $38(34 \%)$ and $36(32 \%)$ samples were sero-positive for B. equi infection and B. caballi infection, respectively. In addition, 14 (12\%) samples were sero-positive for both B. equi and B. caballi as a mixed infection.

The highest prevalence was among age group ranged from 5-10 years as (22.81\%) (34 included 29 male and 5 female). The age may play a role in the infestation of horses with T.equi as old animals especially if working hard are under stress and immune suppressed for that they are susceptible to infestation with T.equi.

The highest prevalence was in July and was recorded as $(25.81 \%)$ and the disease was more prevalent in summer than in winter as previously described in table-3. That could be explained by the summer season is the suitable time for ticks multiplications accordingly spread the infestations of T.equi to ticks infested horses. That was proved [18], they confirmed transmission of T. equi from tick to horses by using indirect immunofluorescence antibody test (IFA).

The highest prevalence was recorded in Nazletalsamman as $(51.61 \%)$. This could be explained by presence of heavy ticks infestation among horses in Nazlet-alsman region. The role of ticks in transmission of T.equi was reported [13], who mentioned that T. equi are transmitted by ticks, which become infected when they ingest parasites in the blood of infected equids. Approximately 14 species of ticks in the genera Dermacentor, Hyalomma and Rhipicephalus can be vectors for these organisms.

The variation in the prevalence of T.equi according to age, sex, months of year and regions is recorded in our study as presented in tables (2,3 and 4), that is in concordance with that reported [10], they stated that the effects of the variation of the prevalence has been observed with different categories and breeding systems in different regions. The management of the horses appears to be an important factor for the prevalence of T. equi infections. Among horses raised with access to pasture there was a significant difference in the seropositive percentage of reactors $(15.05 \%)$ compared with horses without access to pasture (55\%).

Equine babesiosis was clinically characterized by oedema (Figure-2) that could be explained by decrease in the mean total serum protein due to haemolytic anaemia which lower the blood osmotic pressure. Anaemia was also recorded in the infested horses that resulted from infection of the RBCs by the Theilleria Merozites which distucted the cell wall of the RBCs 


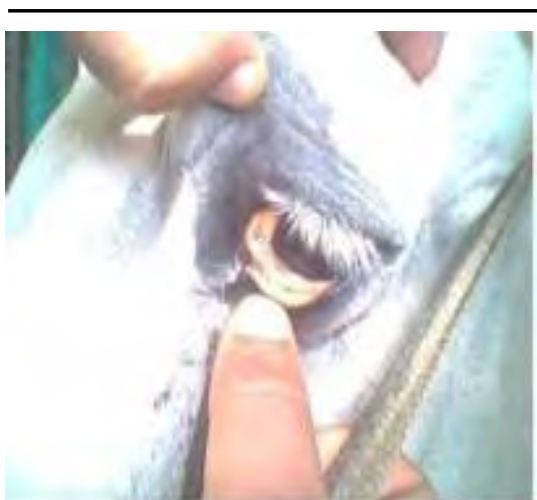

Figure-1.Icteric mucous membrane in Theileria equi infested horse

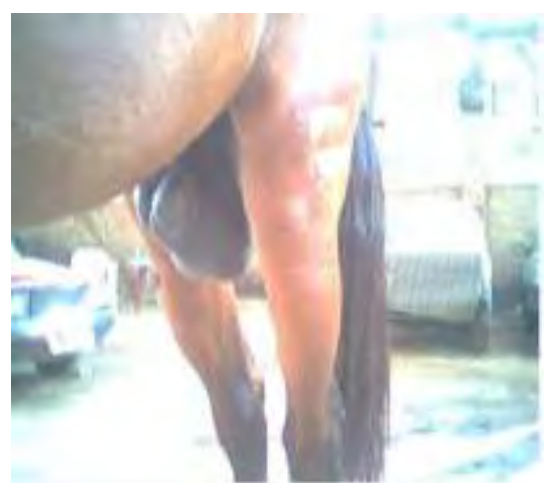

Figure-2. Scrotal oedema in Theileria equi infested horse

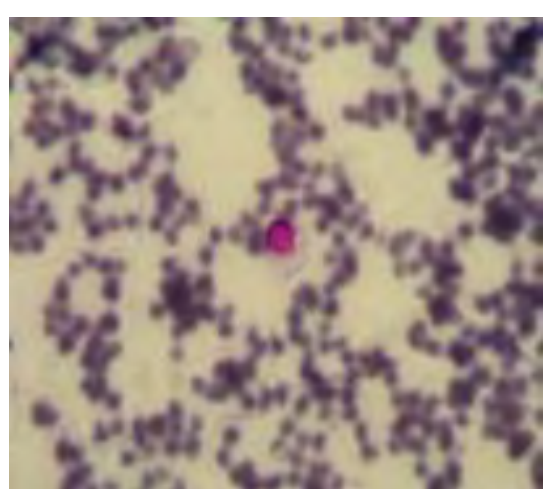

Figure-3. Schizont of Theileria equi in Iymphocyte of infested horse in Giemsa stained blood smear (100X).

Table-7. Assessment of anti-Theileria equi drugs for treatment of T.equi infection by blood smear, clinicalimprovement and serological tests.

\begin{tabular}{|c|c|c|c|c|c|c|c|c|c|}
\hline \multirow[t]{2}{*}{ Group } & \multirow[t]{2}{*}{ Animal } & \multicolumn{3}{|c|}{$\begin{array}{l}\text { Parasitemea(no of lymphocyte/ } \\
\text { blood smear) }\end{array}$} & \multirow{2}{*}{$\begin{array}{l}\text { Clinical improvement } \\
\text { (subsiding of fever and } \\
\text { increased appetite) } \\
\text { PT } \\
\text { (day) }\end{array}$} & \multicolumn{2}{|c|}{$\begin{array}{c}\text { Serological tests } \\
\text { IFA } \\
\text { (at the best dilution } 1 / 160 \text { ) }\end{array}$} & \multicolumn{2}{|c|}{ CFT } \\
\hline & & $\begin{array}{l}\text { BT } \\
\text { (day) }\end{array}$ & $\begin{array}{c}\text { PT } \\
\text { (5 day) }\end{array}$ & $\begin{array}{c}\text { PT } \\
\text { (30 day) }\end{array}$ & & BT & PT & BT & PT \\
\hline \multirow[t]{10}{*}{$A$} & 1 & ++ & + & - & $5^{\text {th }}$ & ++ & + & $1 / 128$ & $1 / 64$ \\
\hline & 2 & + & + & - & $4^{\text {th }}$ & + & + & $1 / 64$ & $1 / 32$ \\
\hline & 3 & ++ & + & - & $4^{\text {th }}$ & + & - & $1 / 64$ & $1 / 8$ \\
\hline & 4 & + & - & - & $4^{\text {th }}$ & + & - & $1 / 32$ & $1 / 16$ \\
\hline & 5 & + & - & - & $4^{\text {th }}$ & + & + & $1 / 64$ & $1 / 32$ \\
\hline & 6 & + & - & - & $5^{\text {th }}$ & + & + & $1 / 8$ & $1 / 8$ \\
\hline & 7 & ++ & + & - & $4^{\text {th }}$ & + & + & $1 / 64$ & $1 / 64$ \\
\hline & 8 & ++ & - & - & $5^{\text {th }}$ & + & + & $1 / 64$ & $1 / 32$ \\
\hline & 9 & ++ & - & - & $5^{\text {th }}$ & ++ & + & $1 / 64$ & $1 / 32$ \\
\hline & 10 & + & - & - & $5^{\text {th }}$ & + & - & $1 / 8$ & $1 / 8$ \\
\hline \multirow[t]{10}{*}{ B } & 1 & ++ & - & - & $4^{\text {th }}$ & + & + & $1 / 64$ & $1 / 32$ \\
\hline & 2 & + & - & - & $4^{\text {th }}$ & + & + & $1 / 64$ & $1 / 16$ \\
\hline & 3 & ++ & + & - & $5^{\text {th }}$ & + & + & $1 / 64$ & $1 / 8$ \\
\hline & 4 & ++ & + & - & $4^{\text {th }}$ & + & + & $1 / 64$ & $1 / 64$ \\
\hline & 5 & +++ & + & - & $4^{\text {th }}$ & + & - & $1 / 64$ & $1 / 16$ \\
\hline & 6 & + & - & - & $3^{\text {rd }}$ & + & + & $1 / 128$ & $1 / 64$ \\
\hline & 7 & ++ & - & - & $5^{\text {th }}$ & + & - & $1 / 64$ & $1 / 32$ \\
\hline & 8 & + & - & - & $5^{\text {th }}$ & + & - & $1 / 64$ & $1 / 32$ \\
\hline & 9 & ++ & + & - & $5^{\text {th }}$ & + & - & $1 / 128$ & $1 / 128$ \\
\hline & 10 & + & - & - & $5^{\text {th }}$ & + & - & $1 / 8$ & $1 / 8$ \\
\hline \multirow[t]{10}{*}{ C } & 1 & ++ & + & - & $4^{\text {th }}$ & + & + & $1 / 128$ & $1 / 32$ \\
\hline & 2 & + & - & - & $4^{\text {th }}$ & + & + & $1 / 64$ & $1 / 16$ \\
\hline & 3 & + & - & - & $6^{\text {th }}$ & + & - & $1 / 16$ & $1 / 16$ \\
\hline & 4 & ++ & - & - & $5^{\text {th }}$ & + & + & $1 / 64$ & $1 / 16$ \\
\hline & 5 & ++ & - & - & $5^{\text {th }}$ & + & + & $1 / 64$ & $1 / 8$ \\
\hline & 6 & + & - & - & $4^{\text {th }}$ & - & - & $1 / 16$ & $1 / 16$ \\
\hline & 7 & + & - & - & $4^{\text {th }}$ & - & - & $1 / 16$ & $1 / 16$ \\
\hline & 8 & ++ & - & - & $4^{\text {th }}$ & + & + & $1 / 32$ & $1 / 64$ \\
\hline & 9 & ++ & + & - & $5^{\text {th }}$ & + & - & $1 / 16$ & $1 / 16$ \\
\hline & 10 & ++ & - & - & $5^{\text {th }}$ & + & - & $1 / 64$ & $1 / 32$ \\
\hline \multirow[t]{10}{*}{ D } & 1 & + & - & - & $4^{\text {th }}$ & ++ & + & $1 / 128$ & $1 / 64$ \\
\hline & 2 & + & - & - & $4^{\text {th }}$ & $\begin{array}{l}\text { TT } \\
+\end{array}$ & + & $1 / 64$ & $1 / 32$ \\
\hline & 3 & + & + & - & $3^{\text {rd }}$ & + & + & $1 / 64$ & $1 / 64$ \\
\hline & 4 & ++ & + & - & $4^{\text {th }}$ & + & - & $1 / 64$ & $1 / 16$ \\
\hline & 5 & $\begin{array}{l}++T \\
++\end{array}$ & + & - & $4^{\text {th }}$ & + & + & $1 / 64$ & $1 / 8$ \\
\hline & 6 & ++ & - & - & $3^{\text {td }}$ & + & + & $1 / 64$ & $1 / 16$ \\
\hline & 7 & ++ & - & - & $4^{\text {th }}$ & + & + & $1 / 64$ & $1 / 16$ \\
\hline & 8 & + & - & - & $3^{\text {rd }}$ & + & - & $1 / 64$ & $1 / 8$ \\
\hline & 9 & ++ & + & - & $4^{\text {th }}$ & + & - & $1 / 64$ & $1 / 8$ \\
\hline & 10 & ++ & - & - & $5^{\text {th }}$ & + & - & $1 / 8$ & $1 / 8$ \\
\hline
\end{tabular}

causing haemolytic anaemia. Icterus (Figure-1) was observed in Theileria equi infested horses that could be happened due to increase in serum concentration of bilirubin which discoloured tissues including mucous membranes and body fluid. [13,16]. Deaths from $T$. equi infection among horses was not recorded in our study because it usually happen in peracute form of the disease. It is caused by severe haemolytic anaemia and destruction of RBCs that released toxins and disseminated intervascular coagulation in the vascularity of the brain $[6,13]$.

The changes in blood and chemistry were recorded where the number of RBCs decreases due to it's destruction by piroplasmoses causing anemia. The haemoglobin decreased due to destruction of RBCs. Bilirubin was increased as a result of pre-heapatic jaunedice caused by haemolytic anaemia $[13,16]$. When RBCs were destructed; haemoglobin released then it was destructed to haem and globin. The Haem part was converted into biliverdine by oxygenase enzyme and consequently biliverdine was converted into bilirubin by reductase enzyme. Liver enzymes were elevated due to the increased amount of unconjugated bilirubin, at the same time the liver has certain capacity 
Table-8. Assessment of anti-Theileria equi drugs for treatment of T.equi infection by blood picture and blood chemistry.

\begin{tabular}{|c|c|c|c|c|c|c|c|c|c|}
\hline $\begin{array}{l}\text { Group } \\
\text { (mean) }\end{array}$ & \multicolumn{2}{|c|}{ No. of horses } & \multirow{3}{*}{$\begin{array}{l}\text { Blood Picture } \\
\text { Haemoglobin } \\
\text { (g/dl) }\end{array}$} & \multirow{2}{*}{$\begin{array}{l}\text { B lood chemistry } \\
\text { Total R B Cs Count } \\
\text { Million / } \mu \text { l }\end{array}$} & \multirow{3}{*}{$\begin{array}{l}\text { PCV (\%) } \\
20 \\
45\end{array}$} & \multicolumn{2}{|c|}{$\begin{array}{l}\text { Bilirubin (mg/dl) } \\
\text { Total Direct }\end{array}$} & \multirow{2}{*}{$\begin{array}{l}\begin{array}{l}\text { Liver } \\
\text { ALT }\end{array} \\
356\end{array}$} & \multirow{3}{*}{$\begin{array}{l}\text { Enzymes (u/L) } \\
\text { AST } \\
455 \\
175\end{array}$} \\
\hline (A) & 10 & BT & & & & 5.6 & 1.7 & & \\
\hline & & PT & & $4,420,000$ & & 2.1 & 0.3 & 172 & \\
\hline \multirow[t]{2}{*}{ (B) } & 10 & BT & 9.5 & $3,460,000$ & 33 & 6.2 & 2.9 & 423 & 378 \\
\hline & & PT & 12.8 & $4,420,000$ & 43 & 1.8 & 0.5 & 285 & 183 \\
\hline \multirow[t]{2}{*}{ (C) } & 10 & BT & 9.5 & $3,460,000$ & 33 & 4.9 & 2.5 & 467 & 343 \\
\hline & & PT & 13.2 & $4,660,000$ & 44 & 2.5 & 0.1 & 163 & 194 \\
\hline \multirow[t]{2}{*}{ (D) } & 10 & BT & 7.9 & $2,670,000$ & 22 & 4.6 & 1.6 & 389 & 386 \\
\hline & & PT & 14.7 & $4,890,000$ & 47 & 2.3 & 0.7 & 277 & 211 \\
\hline \multicolumn{3}{|c|}{ Normal value } & $11-19$ & 6.8-12.9 millions & $32-53$ & $0.2-2.9$ & $0.0-0.8$ & $150-294$ & $102-257$ \\
\hline
\end{tabular}

$\mathrm{BT}=$ before treatment $\quad \mathrm{PT}=$ post treatment (one month)

to conjugate bilirubin so with continous release of haemoglobin and formation of unconjugated bilirubin the level of liver enzymes increased [16].

As previously illustrated in table-5, the best dilution for IFA was $1 / 160$ where sensitivity, specificity and accuracy were the highest for this test as (98\%), $(92.86 \%)$ and $(97.44 \%)$ respectively. The same results were recorded [15], who mentioned that the sensitivity and specificity of IFA were $89.2 \%$ and $99.0 \%$ respectively. While for CFT, the best dilution was $1 / 32$ where sensitivity, specificity and accuracy were collectively the best as $(90 \%),(92.86 \%)$ and $(90.74 \%)$ respectively. That disagree with that recorded [15], they found that the CFT sensitivity and specificity for diagnosis of $T$. equi were $63.1 \%$ and $96.4 \%$, respectively. At the comparison of IFA 1/160 and CFT $1 / 32$ we found that IFA has the higher sensitivity, specificity and accuracy. So it is preferable to use IFA at dilution 1/160 for diagnosis of equine babesiosis than CFT. That agrees with that reported [13], indirect fluorescent antibody test is the primary tests used for qualifying horses for the importation. The test has been proved more effective in detecting long-term infected animals and animals treated with antiparasitic drugs but these animals may be CFT negative but still be infected.

The false positive results of IFA and CFT could be explained by firstly, treatment with protozoal drug elemenate the protozoan from RBCs but the antibodies is found in serum. And secondly, by infection of Equines with T. equi appeared to remain permanent. Parasitemia was often absent in carriers, but can reoccur after immuno-suppression or strenuous exercise. T. equi can be passed to the foal in utero, and some foals can be healthy carriers.

The false negative results of IFA and CFT could be explained by the early infection by T.equi where they were found inside RBCs but the antibodies were not formed yet or the immune system was suppressed and did not react to form antibodies that occurred in too young or too old equines.

The kappa value (the degree of agreement) of the IFA and CFT as illustrated in table (6) showed that the best value was at IFA $1 / 320$ and CFT $1 / 128$ as (1) that means complete agreement while the worst value was at IFA $1 / 320$ and CFT $1 / 8$ as (0.02) that means slight agreement. Complement fixation test has been selected as the test of choice for diagnosis of Theileria equi infection in several countries, allowing detection of acute cases and chronic carriers, becoming negative soon after treatment. IFA is even more sensitive and recommended in combination with CFT [13].

Although the four anti-theileria medications regimens have different medications, doses, routes of administrations and modes of actions they have the same ability to eradicate T.equi from horse blood and improve clinical signs, blood pictures, blood biochemistry and also lower antibody titres in sera of infected horses that were very clear at one month posttreatment.

Imidocarb dipropionate is a derivative of the carbanilide antiprotozoals. Although the exact mode of action of the drug is not known, a possible mechanism is interference with cellular repair and replication through binding with DNA. Imidocarb is highly effective against infections caused by Theileria.

Our results disagree with other authors reported that although there are different anti-theileria drugs, imidocarb dipropionate is the drug of choice for equine theileriosis. It has a widespread distribution in body fluids and tissue. Plasma concentration of imidocarb was not still detectable twelve hours after administration. It could be administered intramuscularly or subcutaneously, but not intravenously. The precise mode of action against piroplasmosis is not yet clearly understood. It is thought to involve the compound's combination with nucleic acids, causing partial uncoiling and denaturation of the DNA double helix of the parasite. Imidocarb also inhibits the entry of inositol into the parasitised erythrocyte and therefore leads to "starvation" of the parasite [9].

Diminazene aceturite has effect on the Theileria, it appears to relate to interference with aerobic glycolysis, as well as with synthesis of DNA in the parasite.

We also observed that the diminazene diaceturate causes swelling and necrosis at the injection sites that agrees with that reported [9]. In addition to toxic doses of diminazene diaceturate may result in respiratory distress, depression and other signs of intoxication [9].

In our study, the dose of imidocarb was $120 \mathrm{mg} /$ $100 \mathrm{~kg}$ body weight, it eliminate T.equi, improve clinical signs and leave undetectable traces of the parasite that stimulate immune system cause horse 
immune against new infection. That agrees with that the only report of elimination of $T$. equi was from a trial with imidocarb treatment, used at a dosage rate of 4 $\mathrm{mg} / \mathrm{kg}$ body weight [9]. Buparvaquone is a secondgeneration of hydro-xynaphthoquinone. It is effective in the control and prophylaxis of all forms of theileriosis. The mode of action of buparvaquone on Theileria is not yet established, although there are indications that there is an effect on energy generation.

\section{Conclusion}

T.equi is prevalent among horses in Giza governourate. It could be diagnosed by blood films, serology, blood picture, blood chemistry and it could be treated successfully by one of the four medications regimens we used. We also recommend that the eradication of ticks by the use of acaricides through national program, the frequent examination of the horses and immediate treatment of any ticks infected horses to prevent infection.

\section{Author's contribution}

All authors contributed equally. All authors read and approved the final manuscript.

\section{Acknowledgements}

Authors are pleased to thank the Department of Medicine and Infectious Diseases, Faculty of Veterinary Medicine, Cairo University and Animal Health Research Institute, Dokki, Giza and El-Haram Reproduction Institute for providing the laboratories and devices during this research work.

\section{Competing interests}

Authors declare that they have no competing interests.

\section{References}

1. Abutarbush, S.M., Alqawasmeh, D.M., Mukbel, R.M., AlMajali, A.M.(2012).Equine babesiosis: seroprevalence, risk factors and comparison of different diagnostic methods in Jordan.Transbound. Emerg. Dis.; 59(1):72-78.

2. Adaszek, Ł., Górna, M., Krzysiak, M., [2], M., Garbal, M., Winiarczyk, S.(2011).Identification of the piroplasms isolated from horses with clinical piroplasmosis in Poland. Wiad. Parazytol,57(1):21-26.

3. Alanazi, A.D.; Alyousif, M.S. and Hassieb, M.M.(2012): Seroprevalence study on Theileria equi and Theileriacaballi antibodies in horses from Central province of Saudi Arabia. J. Parasitol. 2012 Apr 10 (Epub ahead of print).

4. Butler, C.M.; Sloet van Oldruitenborgh-Oosterbaan, M.M.; Stout, T.A.; van der Kolk, J.H.; Wollenberg, L.V.; Nielen, M.; Jongejan, F.; Werners, A.H. and Houwers, D.J. (2012):Prevalence of the causative agents of equine piroplasmosis in the South West of The Netherlands and the identification of two autochthonous clinical Theileria equi infections. Vet. J. Jan 20 (Epub ahead of print).

5. Cantu-Martínez, M.A.; Segura, J.C.; Silva-Páez, M.L.; Avalos-Ramirez, R. and Wagner, G.G.(2012).Prevalence of Antibodies to Theileria equi and Theileriacaballi in Horses From Northeastern Mexico. J. Parasitol. Feb 16. (Epub ahead of print).

6. Coles, E. H. (1986): Veterinary Clinical Pathology. 4th edn.W.B. Saunders. Philadelphia.

7. Dawson -Saunders, B.and Trapp,R.G. (1990).Reading the Medical Literature in:basic and Clinical Biostatistics
Appleton and Lange. Cited in Vet.Epidemiology, Principles and Methods, 1987.Lowa State University Press/Ames.

8. Hanan, A. Tag El-Din; Abbas, H.E. and Amany, Y.M.Rashed (2007): Influence of dimenazine aceturate on hematological and biochemical parameters in horses affected with babesia. J. Egypt. Vet.Med.Assoc. 67 (3) 17-29.

9. Janina Kutscha (2008): Effects of Specific Equine Babesiosis Treatments on Equine Oro-caecal Transit Time as measured by the Lactose ${ }^{13} \mathrm{C}$-Ureide Breath Test. PhD thesis, the Faculty of Veterinary Medicine of the LudwigMaximilians-University Munich. Pp:27-32.

10. Leandro,Q.N.; Marcelo,M.G.; Samuel, R. F.; Sergio, S.S. and Carlos, E.W.N. (2008): Frequency of seropositive equines for Theileria equi in the Southern Rio Grande do Sul State, Brazil. Parasitol Latinoam, 63:46-50.

11. Machado, R.Z., Toledo, C.Z, Teixeira, M.C., André, M.R., Freschi, C.R., Sampaio, P.H.(2012).Molecular and serological detection of Theileria equi and Babesia caballi in donkeys in Brazil. Vet Parasitol. 186(3-4): 461-465.

12. Mujica, F.F., Perrone, T., Forlano, M., Coronado, A., Meléndez, R.D., Barrios, N., Alvarez, R., Granda, F. (2011). Serological prevalence of Babesia caballi and Theileria equi in horses of Lara State, Venezuela. Vet. Parasitol.,178(1-2):180-183.

13. OIE (2008) Equine Piroplasmosis (Equine Babesiosis, Equine Theileriosis, Biliary Fever). August 29, 2008., Pp:1-5.

14. OIE, Terrestrial Manual, (2008): chapter 2.5.8, equine piroplasmosis, Pp: 886-890.

15. Oladele, O.; Marios, P. G.; Gary, H.; Jane, B.; Kurt, P. and Lopez-Rebollar, L. (2007): Validation of the indirect fluorescent antibody and the complement fixation tests for the diagnosis of Theileria equi. Vet. Parasitol. 148: 102-108.

16. Radostitis, O.M.; Gay, C.C.; Hinchcliff, K.W. and Constable, P.D. (2008): Textbook of Veterinary Medicine, $10^{\text {th }}$ edition, 2008 print.; printed by El-sevier, Spain, ISBN: 978-0-7020-2777-2, pp.1421-1423.

17. Rirgelman,R.K and Hirsch,R.P. (1989):Cited in Studying a Study in :Studying a Study and Testing a Test. $2^{\mathrm{ND}}$ ED. Little, Brown.

18. Schwint, O.N.; Ueti, M.W.; Palmer, G.H.;Kappmeyer, L.S.; Hines, M.T.; Cordes, R.T.; Knowles, D.P. and Scoles, G.A. (2009). Imidocarb dipropionate clears persistent Theileriacaballi infection with elimination of transmission potential.Antimicrob. Agents Chemother., 53(10):4327-4332.

19. Seo, M.G., Yun, S.H., Choi, S.K., Cho, G.J., Park, Y.S., Kwon, O.D., Cho, K.H., Kim, T.H., Jeong, K.S., Park, S.J., Kwon, Y.S., Kwak, D.(2011).Seroprevalence of equine piroplasms in the Republic of Korea. Vet. Parasitol.,179(13):224-226.

20. Sloboda, M., Jirků, M., Lukešová, D., Qablan, M., Batsukh, Z., Fiala, I., Hořín, P., Modrý, D., Lukeš, J. (2011). A survey for piroplasmids in horses and Bactrian camels in NorthEastern Mongolia. Vet. Parasitol., 179(1-3):246-249.

21. Steinman, A., Zimmerman, T., Klement, E., Lensky, I.M., Berlin, D., Gottlieb, Y., Baneth, G.(2012). Demographic and environmental risk factors for infection by Theileria equi in 590 horses in Israel. Vet Parasitol. 2012 Jan 17 (Epub ahead of print).

22. Wayne Martin, S.;Alan, H.Meek and PreBen Wile Berg (1987): Vet.Epidemiology, Principle and Methods. Lowa State University Press/Ames.

23. Xu Y, Zhang S, Huang X, Bayin C, Xuan X, Igarashi I, Fujisaki K, Kabeya H, Maruyama S, Mikami T.(2003). Seroepidemiologic studies on Theileriaequi and Theileriacaballi infections in horses in Jilin province of China. J Vet Med Sci. 2003 ;65(9):1015-1017.

24. Zweygarth, E.; Lopez-Rebollar, L.M. and Meyer, P. (2002): In vitro isolation of equine piroplasms derived from Cape Mountain zebra (Equus zebra zebra) in South Africa. Onderstepoort J. Vet. Res., 69(3):197-200.

$* * * * * * * *$ 